\title{
Relationship between knowledge and adolescent social environment with inhalation abuse (fox glue)
}

\author{
Defi Anna Losita ${ }^{1}$, Rika Damayanti ${ }^{2}$ \\ ${ }^{1}$ Universitas Aisyah Pringsewu Lampung \\ ${ }^{2}$ Universitas Islam Negeri Raden Intan Lampung \\ bk.deviana@gmail.com
}

Submitted : 30-04-2021, Revised : 23-05-2021, Accepted : 24-05-2021

\begin{abstract}
This study was to determine the relationship between knowledge about the dangers of inhalationand the social environment of adolescents to the abuse of Fox glue. This study used a Cross-Sectional Design experimental design. The research subjects used in this study were 64 adolescents in the Pidada Panjang village, Bandar Lampung. Selection of subjects using simple random sampling technique by taking samples from members of the population at random without considering the existing strata. In this study, using data collection techniques with three instruments, the first instrument is knowledge of inhalation hazards (Asti, 2014), the second instrument is the influence of the social environment (Hidayat, 2016), and the third instrument of inhalation abuse changed by the researchers themselves. The data analysis technique used was Univariate and Bivariate. The results showed that there was a relationship between knowledge about the dangers of inhalation ( $p$-value $=0.003$ ) and the social environment of adolescents ( $p$-value $=0.000)$ on the abuse of Fox glue. The findings of this study prove that knowledge about the dangers of inhalation and the social environment is related to the prevention of inhalation abuse (Fox glue) in adolescents. The higher the knowledge about the dangers of inhalation and a good social environment, the higher the preventive measures against inhalation (Fox glue)

Keywords: Adolescent social environment; Fox glue; Knowledge of the dangers of inhalation
\end{abstract}

\section{Introduction}

The young generation is the backbone that plays a role in making an important contribution to the era of the demographic bonus later. However, the massive abuse of addictive substances by the nation's generation will be the worst threat that will create the phenomenon of lost generations in the future. The annual report of the United Nations Office on Drugs and Crime (UNODC) states that in absolute terms there are about 167 to 315 million people who abuse narcotics, psychotropic substances, and dangerous addictive substances (NAPZA).

This figure comes from the world's population aged between 15 and 64 years (Berkas et al., 2017; Edar, 2017). Research results from the National Narcotics Agency (BNN) in Indonesia, drug abuse is included in the critical category with 3.8 million to 4.1 million people or around $2.10 \%$ to $2.25 \%$ of the total population of Indonesia. Drug abuse has major implications for the health and socio-economic losses of the country, and in one year as many as 18,000 people die from narcotics (Nasional, 2019).

Data from the survey on drug abuse by the National Narcotics Agency for 3,376,115 people in 2017 found that 810,267 people were students and 573,939 were from the general population group. As for the results of the survey based on gender, $72 \%$ of drug abusers are men and 28\% are women (Nasional, 2019), 2017 the Komisi Perlindungan Anak Indonesia stated there are 87 million child populations in Indonesia, of which 5.9 million are drug addicts (Hartini, 2017).

The number of victims of drug abuse in Indonesia has recently increased. Currently, the interest and trend for adolescents, especially street children, is inhalant drugs, which are relatively cheap and easy to get (Aswadi et al., 2018). Inhalant abuse is the deliberate inhalation of volatile substances to get a euphoric effect, to feel safe, free, and exciting. Glue is a type of volatile substance abuse source (Ramón et al., 2003), and has now penetrated the 
lower layers of society by involving the general population, including adolescents such as students, students, and those who have broken families where students are forced. To live on the street to become scavengers, unemployed, and enter gang groups (Praharaj et al., 2008; Reddy et al., 2020).

Fox brand adhesive glue contains addictive substances, namely Lysergic Acid Diethylamide abbreviated as ASD or Lysergic Acid Diethylamide / LSD) which is also called "Acid" (King, 2019). This substance was discovered by Albert Hoffman, a chemist from Switzerland (Carhart-Harris et al., 2016). Acid is a semi-synthetic psychedelic drug from the ergoline class, known for its psychological effects, which increase the ability to think, visual / hallucinations (Cortés-Cartagena, 2020; Ravisankar et al., 2018), both in closed and open eyes, synaesthesia (confusion of the senses, for example: listening to colors, seeing songs), as well as time distortions (Libânio Osório Marta, 2019; Nichols, 2018). If the liquid glue is inhaled deeply, it can have a floating effect as felt by drug users (Diniaty et al., 2019), and has a very strong potential to cause dependence on users (Aswadi et al., 2018).

The effects of inhaling Fox glue include loss of emotional control, disorientation, depression, dizziness, feelings of acute panic, and feelings of unbeatable doglegging (Csiernik, 2019; Mardal et al., 2017; Thulasirajah et al., 2020). This effect causes users to put themselves in the act of hurting themselves and harming others (Sattler et al., 2017). Misuse of fox glue can damage the health of its users (Djurendic-Brenesel et al., 2016; Manikandan \& Balasubramanian, 2020; Mishra et al., 2018; Yurtseven et al., 2018), the smell of glue inhaled through the respiratory tract results in physical and psychological dependence (Daley et al., 2020; Khasanah, 2019). In addition, a definite risk is a damage to the nervous system and other important organs, such as the heart, lungs, liver, which ultimately leads to death (Broussard, 2020; Pérez-Gómez et al., 2020). In addition, a definite risk is a damage to the nervous system and other important organs, such as the heart, lungs, liver, which eventually causes death (Broussard, 2020; Pérez-Gómez et al., 2020).

Mostly the fox glue users are those who have a low economy (Kalra, 2018; Koposov et al., 2018; Pitoyo \& Kurniawan, 2021; Vázquez et al., 2019), especially teenagers who work on the streets (Jhakar et al., 2017; Lakshmana, 2019; Sah et al., 2020). Working hours on the streets are tiring and draining, prompting teenagers to try using affordable fox (Dhawan et al., 2020; Masud \& Khan, 2018). Production of LSD contained in Fox glue cannot be banned, because it acts as an adhesive. Even though many of the teenagers who work on the streets abuse Fox glue, there are still teenagers who have not fallen victim to it. Unfortunately, those who have not fallen victim are very vulnerable to trying to abuse Fox glue because of the seduction of friends and unwillingness to be weak or underestimated. Knowledge and belief in the dangers of fox glue will be a stimulus for adolescents not to abuse it (Dunn et al., 2017; Rawas et al., 2020; Van Ryzin et al., 2016). This knowledge determines the attitude taken. The more knowledge and beliefs of adolescents about the impact or danger of using fox glue for themselves will encourage the behavior to avoid the abuse of fox glue (Pagliaro \& Pagliaro, 2019; Sehra \& Patnaik, 2017). Fadli \& Suwandewi (2019) found that there was a significant relationship between adolescent knowledge and the tendency to use drugs (fox glue) in adolescents at the Shelter House in Banjarmasin City of 0.841 , which was very strong, ranging from 0.76 to 1.00 .

National Narcotics Agency of the Ministry of Health has not released data on the misuse of fox glue in adolescents. However, several studies were conducted and showed that the highest inhalation activity was 15-18 years. Adolescents against drug abuse because of their emotional and mental instability and are easily influenced by deviant behavior (Azriful et al., 2016). Based on data from the Ministry of Health of the Republic of Indonesia, data on inhalation of abuse in Lampang Province has increased from year to year. In 2000 there were 510 users, 2001 totaled 535 and in 2012 there were 647 users (Berkas et al., 2017; Edar, 
2017). The preliminary study was conducted by interviewing 10 adolescents in Pidada Village, Bandar Lampung, seven were male and three were female. Teens work as presses for roadside tires, newspaper sales agents, and buskers. Interviews were conducted on 17-19 July 2020 in Pidada Panjang Village, Bandar Lampung. The results of the interview revealed that out of ten teenagers, seven people like to smell fox glue. According to the teenager, the money he gets from work is sometimes used to buy Fox glue. This teenager reveals his experience inhaling Fox glue. Initially, nothing happened, but after a while, the adrenaline rushed up. He became very confident, courageous, and fearless.

Fox glue abuse among adolescents has been very worrying, especially if it is not immediately addressed it will become a threat to the welfare of future generations (Hasibuan, 2018; Marsaid, 2015; Solichin, 2017; Utomo, 2017). Preventive countermeasures must be socialized with various efforts. Fox glue abuse is by continuous or occasional excessive inhalation (Bouchatta et al., 2016; Djurendic-Brenesel et al., 2016). This abuse can cause disturbances to both bodies of a person, followed by unwanted social consequences (Alunni et al., 2018; Jayanth et al., 2017). Factors that influence inhalation abuse are external factors, namely environment and internal factors, namely knowledge and (Crossin et al., 2017; Munawar et al., 2020), family environment, association, and characteristics that include age and knowledge/education factors (Crossin et al., 2019). Internal factors relate to mental, physical, and psychological conditions which are determined by biological aspects, namely genetics. On the psychological aspect, namely lack of self-confidence, inability to manage problems, trial and error, and adventure to gain new experiences can cause a teenager to fall into substance abuse (Kusmiran, 2011; Rawas et al., 2020).

Adolescents who have little or no knowledge of the dangers of inhalation will dare to use them, causing addiction. Likewise, adolescents who are mediocre about using Fox glue will easily get persuasion from their friends who have used them, coupled with the situation of teenagers who mostly work on the streets and abuse a lot of Foxes glue, it will make it easier for them teenagers to fall into a trap.

The next factor of Fox glue abuse is the social environment of adolescents. According to Kusmiran (2011). Environmental factors that can cause the abuse of Fox glue include relationships with family, the influence of friends, and certain environments. Excessive protection from parents often neglects the individuality of the child, forcing children to be successful and prestigious can encourage children to flee to dreamland through addictive substances. Friends have a very important role, getting evidence that the influence of friends is the principal reason for first use (Kelly et al., 2021; Pennington, 2019).

\section{Methods}

This experimental research uses Cross-Sectional Design. This study looked at population or sample data only once at the same time. The data collected was to determine the relationship between adolescent knowledge about the dangers of breathing and their social environment with the abuse of fox glue.

The selection of this subject used a simple random technique. The subjects in this study were adolescents in Pidada Village, Bandar Lampung, who worked on the streets. The research subjects used in this study were 64 out of 111 adolescents with an age range of 1218 years and comprised 87 boys and 24 girls. This study using data collection techniques with three instruments, the first instrument is knowledge of inhalation hazards (Asti, 2014), the second instrument is the influence of the social (Hidayat, 2016), and the third instrument of inhalation abuse by investigators. The data analysis technique used was univariate and bivariate analysis. Univariate analysis to describe the frequency distribution of each variable, 
and bivariate analysis to determine the relationship between variables, used SPSS 22.0 chisquare test.

\section{Results and Discussion}

All 64 respondents took part in this study. The results of the frequency distribution and characteristics of respondents with the environment of Fox glue abuse.

1. Univariate Analysis

Table 1. Frequency Distribution of Respondent Characteristics

\begin{tabular}{lcc}
\hline \multicolumn{1}{c}{ Variabel } & Frequency & Percentage (\%) \\
\hline Psychotropics and addictive substances (fox glue) & & \\
1. Does not include abuse & 24 & 37,5 \\
2. Including abuse & 40 & 62,5 \\
3. Total & 64 & 100 \\
\hline Inhalation hazard knowledge & & \\
1. Good & 20 & 31,2 \\
2. Enough & 23 & 35,9 \\
3. Not good & 21 & 32,8 \\
4. Total & 64 & 100 \\
\hline Environmental abuse of inhalants & & \\
1. Has no effect & 29 & 45,3 \\
2. Influential & 35 & 54,7 \\
3. Total & 64 & 100 \\
\hline
\end{tabular}

Based on table 1, it is known that 40 or $62.5 \%$ of respondents abused psychotropic substances and addictive substances (fox glue), while 24 or $37.5 \%$ of respondents did not abuse inhalants (fox glue). For knowledge about inhalant hazards, 20 or $35.1 \%$ of respondents had sufficient knowledge, 23 or $31.2 \%$ of respondents had very good knowledge, and 21 or $32.8 \%$ of respondents had insufficient knowledge. In the environment of inhalant abuse, it was found that 35 respondents with a total percentage of $54.7 \%$ were affected by the social environment and 29 respondents with a total percentage of $45.3 \%$ were not affected. Of the 35 respondents who were affected by the social environment, $14.3 \%$ did not abuse psychotropic substances, addictive substances (fox glue), and $85.6 \%$ were put in inhalants (fox glue).

a. Misuse of fox glue

Based on the research results, it is known that 40 or $62.5 \%$ of respondents abused inhalants (Fox glue), while 24 or $37.5 \%$ of respondents did not abuse inhalants (Fox glue). Inhalants have substances that are psychoactive through a selective influence on the central nervous system causing distinctive changes in mental activity and behavior. The addictive substance in Fox glue is a material that can be addictive (FR \& Sutrisna, 2019). The results were supported by Nurlila \& La Fua (2017), from 84 samples, it was found that 31 students (36.9\%) used Fox glue because their high curiosity and curiosity caused students to abuse it.

Inhalation abuse can harm the body, causing users to feel dizzy, unconscious, and can cause liver, heart, and brain disorders (Edelfield \& Moosa, 2011; Glei et al., 2020; Hassan et al., 2017; Jain \& Verma, 2016; Knopf, 2021; Real et al., 2021).

b. Knowledge

Remembers and recognizing objects that have been studied through the five senses in a particular field well (Lilis \& Lestari, 2017). Based on the research results, it was found that 20 or $35.1 \%$ of respondents had sufficient knowledge, 23 or $31.2 \%$ of respondents had excellent knowledge, and 21 or $32.8 \%$ of respondents had poor knowledge. 
The results are in line with Prisaria (2012), the results of the study showed that there was a positive relationship between high school student's knowledge of drugs and drug abuse prevention measures $(\mathrm{p}=0.001 ; \mathrm{r}=0.378)$. These results show that the higher the students' knowledge, the higher the prevention of drug abuse.

c. Social environment

Based on the results of the study, it was found that 35 or $54.7 \%$ of respondents are affected by the social environment, and 29 or $45.3 \%$ of respondents are not affected. Of the 35 respondents who were affected by the social environment, there were $85.6 \%$ included in inhalant abuse (Fox glue), and the remaining $14.3 \%$ were not.

A social environment is a form of relationship between humans and each other that can affect attitudes, behavior between humans, family members, friends, and society (Kusmiran, 2011). The results of this study are in line with Husna et al (2016), which showed a significant relationship between peers and attachment behavior (inhalant abuse).

2. Bivariate Analysis

Table 2.The relationship between knowledge and social environment on inhalant abuse (Fox glue)

\begin{tabular}{ll}
\hline Variable & \multicolumn{1}{c}{ Result } \\
\hline Knowledge & $\mathrm{p}$ value $=0,003$ or $\mathrm{p}<0,05$ \\
& $\mathrm{~N}=64$ \\
\hline $\begin{array}{l}\text { Social } \\
\text { environment }\end{array}$ & $\mathrm{OR}=11,4$ \\
& $\mathrm{P}$ value $=<0,001$ or $\mathrm{P}<0,05$ \\
$\mathrm{~N}=64$
\end{tabular}

(OR: odd ratio)

Based on table 2, the results of the chi-square test p-value $0.003<\alpha(0.05)$, thus it can be concluded that there is a relationship between knowledge of respiratory hazards and the abuse of fox glue in Pidada, Panjang. , Bandar Lampung 2020. The p-value is $0.001<\alpha$ (0.05), it can be concluded that there is a relationship between the social environment of adolescents and the abuse of Fox glue $(\mathrm{OR}=11.4)$ in Pidada Village, Panjang, Bandar Lampung 2020.

a. Knowledge relationship with fox glue abuse

The results showed that 20 or $35.1 \%$ of respondents had sufficient knowledge, $65 \%$ of whom did not abuse Fox glue and 35\% did not. As many as 23 or $31.2 \%$ of respondents have very good knowledge where $34.8 \%$ do not abuse Fox glue and $65.2 \%$ do not. 21 or $32.8 \%$ of respondents have poor knowledge, $14.3 \%$ of them did not abuse Fox glue and $85.7 \%$ did not abuse it.

Based on the results of statistical tests using Pearson's chi-square, the p-value is 0.003 $<\alpha(0.05)$, so it can be concluded that there is a relationship between knowledge and the abuse of inhalants (fox glue) in Pidada Panjang Village. . Bandar Lampung 2020. The results of this study are in line with Firdaus \& Mahargia (2018) and Sulistyawati et al (2014) who argue that there is a positive and significant relationship between the level of knowledge and the attitude of refusing to use drugs.

Knowledge is everything that has been known, understood, recognized as a result of observing or seriously observing an object through the process of sensory interaction. Knowledge is useful for improving the quality and standard of human life and can improve health status (Meidiana et al., 2018). The factors that influence knowledge are education, experience, age, and level of intelligence. According to researchers, knowledge is the basic foundation that a person has to determine attitudes towards things that affect himself and others (Kazmi et al., 2021; Peng et al., 2019; von Stumm, 2017). 
The phenomenon that exists, most of the teenagers who abuse fox glue, are those who dropped out of school or only graduated from elementary or middle school, causing them to have less knowledge about the dangers of inhaling (fox glue). In addition, Panjang is a location close to the port which makes it easier to earn money, causing children and teenagers to choose to drop out of school to work at the port by squeezing (collecting used goods in the back of the truck) and being prone to abuse of fox glue. Many of the respondents believed that there was no negative impact on inhalation abuse (Fox glue). Respondents testified that using Fox glue triggered courage and strength to work, and hallucinations were believed to be real. The effects of the abuse of Fox glue have an enormous impact on the lives of adolescents. Many teenagers fall into casual sex, become entangled in criminal acts such as breaking into community small businesses, and committing immoral acts against close relatives.

Education, experience, age, and intellectual level of adolescents affect the attitude that will be taken. Knowledge and belief in the dangers of inhaled drugs will create stronger selfdefense, and form a strong bull against resistance to the use of drugs (fox glue). Even though some respondents have good knowledge, this is not enough to make adolescents avoid abuse of inhaled drugs, if they still believe that Fox glue does not harm themselves and the environment, therefore, a gradual and comprehensive socialization effort is needed to every teenager in areas prone to abuse. fox glue.

b. The relationship between the social environment and the abuse of fox glue

Based on the results of the study, it was found that 35 respondents with a total percentage of $54.7 \%$ were affected by the social environment and 29 respondents with a total percentage of $45.3 \%$ were not affected. Of the 35 respondents who were affected by the social environment, there were $85.6 \%$ included in inhalant abuse (Fox glue), and the remaining $14.3 \%$ were not included.

Based on the results of the chi-square test, the p-value is $0.000<\alpha(0.05)$, thus it can be concluded that there is a relationship between the social environment of adolescents and the abuse of Fox glue in Pidada, Panjang, Bandar Lampung 2020. The OR (odds ratio) value of 11.4 means the relationship between respondents who have adolescent social environment affects as much as $11.4 x$ on inhalant abuse (Fox glue).

Friends have a very important role in substance/drug abuse. Adolescents who try to stop inhalant abuse (Fox glue) get sanctions from their playmates, namely bullying. This causes adolescents to be burdened and choose to continue the abuse. Adolescents consider the dangers of abuse to be less grievous than the sanctions they get from playmates. Invitations, seduction, and coercion from group friends make adolescents slip into abuse, teenagers are worried about refusing and don't want to be unfaithful friends (Kusmiran, 2011).

Labetubun et al (2018) suggest that the factor of inhalant abuse (Fox glue) by adolescents is caused by curiosity, family disharmony, dependence, and peer influence. Therefore, researchers suggest that the government and related parties take an approach from an early age regarding the impact of the glue-sniffing behavior through non-governmental organizations.

According to researchers, the social environment of adolescents is the factor causing inhalant abuse (Fox glue). The need to socialize encourages adolescents to be fully accepted into the group. Most adolescents who have problems in their family will seek security outside the home from their peers or their social environment. Teens who abuse Fox glue stated that they feel more comfortable and adaptable, talking to other users. Usually, they will gather at a small roundabout near the port at night or at the goods storage area when the goods are going to be sold. 
The abuse of fox glue does not have a time rule, they can breathe in fox glue while they work, which they believe triggers an increase in energy. In one day they can spend three to five fox glue, and if there is no money they just inhale 1 glue.

The effect of abuse of fox glue is hallucinations. Teens are sure to have superpowers, some glue abusers fight without physical resistance, talk to themselves and get angry at walls, talk to chickens, run scared as if someone is chasing and when confirmed they say they are fighting a ghost or their hallucinatory object.

It was found that Fox glue abusers slept at home, although some slept on the front porch of people's houses, most of them did not shower for days, but there were still some who kept clean. Some fox glue abusers were initially just experimenting without environmental influence, to increase their strength and courage to face their opponents, and only a small proportion of respondents were not influenced to abuse Fox glue, because of their high hopes for a wonderful future.

\section{Conclusions and Suggestions}

In the conclusion of this study, there is a significant relationship between knowledge of inhalant hazards and the social environment of adolescents on the abuse of Fox glue. Based on these suggestions, further research is needed to analyze other factors that influence inhalant abuse (Fox glue), so that the research results are more purposeful, the second suggestion is to select a sample grouped based on the same level of education and knowledge.

\section{References}

Alunni, V., Gaillard, Y., Castier, F., Piercecchi-Marti, M., \& Quatrehomme, G. (2018). Death from butane inhalation abuse in teenagers: two new case studies and review of the literature. Journal of Forensic Sciences, 63(1), 330-335.

Asti, Y. (2014). Hubungan Pengetahuan dan Sikap terhadap Perilaku Penyalahgunaan Narkoba pada Siswa/i SMP Negeri 4 Kecamatan Pontianak Timur Kotamadya Pontianak Tahun 2013. Jurnal Mahasiswa PSPD FK Universitas Tanjungpura, 1(1).

Aswadi, A., Kartini, K., \& Sahrir, S. (2018). Perilaku Menghisap (Ngelem) Sebagai Tahap Dini Penggunaan Narkoba Pada Remaja di Kota Makassar. Al-Sihah: The Public Health Science Journal, 10(2).

Azriful, A., Ibrahim, I. A., \& Sulaiman, Y. (2016). Gambaran Pengguna Narkoba Inhalasi (Ngelem) Pada Anak Jalanan di Kota Makassar Tahun 2015. Al-Sihah: The Public Health Science Journal, 8(1).

Berkas, S., Kerjasama, D., Penempatan, V. P. D., \& Penempatan, B. N. (2017). Kementerian Kesehatan Republik Indonesia.

Bouchatta, O., Ouhaz, Z., Ba-Mhamed, S., Kerekes, N., \& Bennis, M. (2016). Acute and chronic glue sniffing effects and consequences of withdrawal on aggressive behavior. Life Sciences, 152, 14-20.

Broussard, L. (2020). Inhalants. In Principles of forensic toxicology (pp. 561-568). Springer.

Carhart-Harris, R. L., Kaelen, M., Bolstridge, M., Williams, T. M., Williams, L. T., Underwood, R., Feilding, A., \& Nutt, D. J. (2016). The paradoxical psychological effects of lysergic acid diethylamide (LSD). Psychological Medicine, 46(7), 1379-1390.

Cortés-Cartagena, M. (2020). Designing an LSD Micro-Dose Transdermal Patch for Mental Illness Drug Therapy. Manufacturing Competitiveness;

Crossin, R., Cairney, S., Lawrence, A. J., \& Duncan, J. R. (2017). Adolescent inhalant abuse leads to other drug use and impaired growth; implications for diagnosis. Australian and New Zealand Journal of Public Health, 41(1), 99-104.

Crossin, R., Qama, A., Andrews, Z. B., Lawrence, A. J., \& Duncan, J. R. (2019). The effect 
of adolescent inhalant abuse on energy balance and growth. Pharmacology Research \& Perspectives, 7(4).

Csiernik, R. (2019). The Essential Guide to Psychoactive Drugs in Canada: A Resource for Counselling Professionals. Canadian Scholars' Press.

Daley, J., Elliott, F. J., Gibbs, T. M., \& Kitteringham, G. (2020). Substance abuse. In The Professional Protection Officer (pp. 233-252). Elsevier.

Dhawan, A., Mishra, A. K., Ambekar, A., Chatterjee, B., Agrawal, A., \& Bhargava, R. (2020). Estimating the size of substance using street children in delhi using respondentdriven sampling (rds). Asian Journal of Psychiatry, 48, 101890.

Diniaty, A., Ernita, M., Afrida, A., Amperawan, D. L., \& Susanti, E. (2019). Peran orang tua mengatasi masalah remaja penghirup lem. Marwah: Jurnal Perempuan, Agama Dan Jender, 17(2), 109-120.

Djurendic-Brenesel, M., Stojiljkovic, G., \& Pilija, V. (2016). Fatal intoxication with toluene due to inhalation of glue. Journal of Forensic Sciences, 61(3), 875-878.

Dunn, K. E., Barrett, F. S., Fingerhood, M., \& Bigelow, G. E. (2017). Opioid overdose history, risk behaviors, and knowledge in patients taking prescribed opioids for chronic pain. Pain Medicine, 18(8), 1505-1515.

EDAR, N. I. (2017). Kementerian Kesehatan Republik Indonesia.

Edelfield, B., \& Moosa, T. J. (2011). Drug Abuse. The Rosen Publishing Group, Inc.

Fadli, M. L., \& Suwandewi, A. (2019). Faktor Yang Berhubungan Dengan Kecenderungan Penggunaan Psikotropika Zat Adiktif (Lem Fox) Pada Remaja. Dinamika Kesehatan: Jurnal Kebidanan Dan KeperawataN, 10(2), 687-699.

FIRDAUS, A., \& MAHARGIA, Y. (2018). Pengetahuan dan sikap Remaja Terhadap Penggunaan NAPZA di Sekolah Menengah Atas di Kota Semarang. Universitas Muhammadiyah Semarang.

FR, J. L., \& Sutrisna, N. (2019). Narkoba, Psikotropika dan Gangguan Jiwa: Tinjauan Kesehatan dan Hukum.

Glei, D. A., Stokes, A., \& Weinstein, M. (2020). Changes in mental health, pain, and drug misuse since the mid-1990s: Is there a link? Social Science \& Medicine, 246, 112789.

Hartini, S. (2017). Peranan Komisi Perlindungan Anak Indonesia (KPAI) terhadap Pelaku Tindak Pidana Anak. YUSTISI, 4(2).

Hasibuan, A. P. (2018). Bimbingan Orang Tua Dalam Mencegah Anak Dari Penyalahgunaan Narkoba Di Jalan Juang 45 Desa Medan Estate Kecamatan Percut Sei Tuan. Universitas Islam Negeri Sumatea Utara Medan.

Hassan, A., Bhatia, S. C., \& Bhatia, S. K. (2017). Inhalant use disorder. Substance and Non Substance Related Addiction Disorders: Diagnosis and Treatment. Bentham e-Books, 136-143.

Hidayat, F. (2016). Dampak Sosial Penyalahgunaan Narkoba Pada Remaja di Kelurahan Kalabbirang Kecamatan Pattallassang Kabupaten Takalar. Universitas Islam Negeri Alauddin Makassar.

Husna, A., Lestari, H., \& Ibrahim, K. (2016). Hubungan Pengetahuan, Teman Sebaya Dan Status Ekonomi Dengan Perilaku Ngelem Pada Anak Jalanan Di Kota Kendari Tahun 2016. (Jurnal Ilmiah Mahasiswa Kesehatan Masyarakat), 1(3).

Jain, R., \& Verma, A. (2016). Laboratory approach for diagnosis of toluene-based inhalant abuse in a clinical setting. Journal of Pharmacy \& Bioallied Sciences, 8(1), 18.

Jayanth, S. H., Hugar, B. S., Praveen, S., \& Girish Chandra, Y. P. (2017). Glue sniffing. Medico-Legal Journal, 85(1), 38-42.

Jhakar, A., Sharma, P., Hossain, S., Yadav, S., \& Sen, V. (2017). Study of Substance Abuse by Street Children in Jaipur City, Rajasthan. Journal of Pharmacy Practice and Community Medicine, 3(3), 176-179. 
Kalra, R. (2018). Unit-3 Substance Abuse. IGNOU.

Kazmi, A. B., Siddiqui, U., \& Siddiqui, S. (2021). Emotional Intelligence: Source Of SelfEfficacy Among College-Level Instructors Of Pakistan. Performance Improvement.

Kelly, P. J., Baker, A. L., Deane, F. P., Callister, R., Collins, C. E., Oldmeadow, C., Palazzi, K. L., Townsend, C. J., Ingram, I., \& Keane, C. A. (2021). Healthy recovery: A stepped wedge cluster randomised controlled trial of a healthy lifestyle intervention for people attending residential alcohol and other drug treatment. Drug and Alcohol Dependence, $221,108557$.

Khasanah, U. (2019). Prevention of Inhalant Abuse Behaviour in Middle High School Students in South Sulawesi 2019.

King, L. A. (2019). Forensic chemistry of substance misuse: a guide to drug control. Royal Society of Chemistry.

Knopf, A. (2021). FDA warns of harms from misuse and abuse of inhalant. Alcoholism \& Drug Abuse Weekly, 33(15), 6-7.

Koposov, R., Stickley, A., \& Ruchkin, V. (2018). Inhalant use in adolescents in northern Russia. Social Psychiatry and Psychiatric Epidemiology, 53(7), 709-716.

Kusmiran, E. (2011). Kesehatan reproduksi remaja dan wanita. Jakarta: Salemba Medika, 21.

Labetubun, R., Ides, S. A., \& Anggraeni, L. D. (2018). Latar Belakang Remaja Menggunakan Lem Aibon. Faletehan Health Journal, 5(1), 1-9.

Lakshmana, G. (2019). Psychosocial Intervention Studies for Street Children with Substance Abuse. In Substance Abuse and Addiction: Breakthroughs in Research and Practice (pp. 391-411). IGI Global.

Libânio Osório Marta, R. F. (2019). Metabolism of lysergic acid diethylamide (LSD): an update. Drug Metabolism Reviews, 51(3), 378-387.

Lilis, L., \& Lestari, S. (2017). Pengaruh Pelaksanaan Sosialisasi P4gn Terhadap Tingkat Pengetahuan Tentang Napza Di Smp Muhammadiyah 8 Yogyakarta. Universitas' Aisyiyah Yogyakarta.

Manikandan, K., \& Balasubramanian, S. (2020). An uprising health concern of inhalant abuse among adolescents: a mini review. Journal of Pharmaceutical Sciences and Research, $12(1), 151-155$.

Mardal, M., Johansen, S. S., Thomsen, R., \& Linnet, K. (2017). Advantages of analyzing postmortem brain samples in routine forensic drug screening-Case series of three nonnatural deaths tested positive for lysergic acid diethylamide (LSD). Forensic Science International, 278, e14-e18.

Marsaid, M. (2015). Laporan Peneilitian Buku Judul; Anak dan Penyalahgunaan Narkoba Menurut Hukum Positif dan Hukum Islam Perspektif Nilai Kepatutan dan Keadilan.

Masud, J. H. B., \& Khan, M. M. (2018). Pattern of drug abuse among street children of dhaka: Inhalants are the most popular drug. Delta Medical College Journal, 6(1), 29-34.

Meidiana, R., Simbolon, D., \& Wahyudi, A. (2018). Pengaruh Edukasi melalui media audio visual terhadap pengetahuan dan sikap remaja overweight. Jurnal Kesehatan, 9(3), 478484.

Mishra, D. R., Bhatta, N., Bista, B., Koirala, P., \& Ghimire, R. (2018). Air due to glue: spontaneous pneumothorax in a young adult with glue sniffing. Journal of the Nepal Medical Association, 56(210).

Munawar, K., Choudhry, F. R., Hadi, M. A., \& Khan, T. M. (2020). Prevalence of and factors contributing to glue sniffing in the South Asian Association for Regional Cooperation (SAARC) region: a scoping review and meta-analysis. Substance Use \& Misuse, 55(5), 752-762.

Nasional, B. N. (2019). Indonesia Drugs Report 2019. Jakarta: Badan Narkotika Nasional.

Nichols, D. E. (2018). Dark classics in chemical neuroscience: lysergic acid diethylamide 
(LSD). ACS Chemical Neuroscience, 9(10), 2331-2343.

Nurlila, R. U., \& La Fua, J. (2017). Penyalahgunaan Zat Adiktif pada Siswa Kelas VIII di Sekolah Menengah Pertama Negeri 05 Kota Kendari. Al-TA'DIB: Jurnal Kajian Ilmu Kependidikan, 10(1), 73-90.

Pagliaro, L. A., \& Pagliaro, A. M. (2019). Child and adolescent drug and substance abuse: A comprehensive reference guide. Routledge.

Peng, P., Wang, T., Wang, C., \& Lin, X. (2019). A meta-analysis on the relation between fluid intelligence and reading/mathematics: Effects of tasks, age, and social economics status. Psychological Bulletin, 145(2), 189.

Pennington, H. (2019). The Parthenon, July 10, 2019.

Pérez-Gómez, A., Cardozo-Macías, F., \& Salcedo-Tocarruncho, L. (2020). Association Between Psychoactive Substance Abuse and Health Disorders in Colombian Problem Drug Users: Second Study. International Journal of Mental Health and Addiction, $18(2), 263-276$.

Pitoyo, A. J., \& Kurniawan, A. (2021). Deviant behaviour in the slum community of Palembang city. IOP Conference Series: Earth and Environmental Science, 683(1), 12129.

Praharaj, S. K., Verma, P., \& Arora, M. (2008). Inhalant abuse (typewriter correction fluid) in street children. Journal of Addiction Medicine, 2(4), 175-177.

Prisaria, N. (2012). Hubungan Pengetahuan Dan Lingkungan Sosial Terhadap Tindakan Pencegahan Penyalahgunaan Napza Pada Siswa Sma Negeri 1 Jepara. Fakultas Kedokteran.

Ramón, M. F., Ballesteros, S., Martinez-Arrieta, R., Jorrecilla, J. M., \& Cabrera, J. (2003). Volatile substance and other drug abuse inhalation in Spain. Journal of Toxicology: Clinical Toxicology, 41(7), 931-936.

Ravisankar, P., Rao, P. R., Babu, P. S., Srikanth, D., Reddy, C. V., Deepthi, O. V., \& Divya, G. (2018). The latest statistical report of the global synthetic drugs. Indian Journal of Research in Pharmacy and Biotechnology, 6(2), 59-64.

Rawas, R. E. L., Amaral, I. M., \& Hofer, A. (2020). Social interaction reward: A resilience approach to overcome vulnerability to drugs of abuse. European Neuropsychopharmacology.

Real, T., Cruz, S. L., Medina-Mora, M. E., Robles, R., \& González, H. (2021). Inhalant addiction. In Textbook of Addiction Treatment (pp. 281-306). Springer.

Reddy, R., Jose, T. G., \& Kingsley, D. (2020). Inhalant Abuses in India: A Review. Indian Journal of Forensic Medicine \& Toxicology, 14(1), 1441.

Sah, S. K., Neupane, N., Pradhan, A., Shah, S., \& Sharma, A. (2020). Prevalence of gluesniffing among street children. Nursing Open, 7(1), 206-211.

Sattler, S., Escande, A., Racine, E., \& Göritz, A. S. (2017). Public stigma toward people with drug addiction: A factorial survey. Journal of Studies on Alcohol and Drugs, 78(3), 415425.

Sehra, L., \& Patnaik, S. (2017). Substance abuse in Punjab on the India-Pakistan border s from anthropology. Acta Criminologica: African Journal of Criminology \& Victimology, $30(1), 1-22$.

Solichin, H. A. (2017). Peran Dinas Sosial dalam Menangani Penyalahgunaan Lem Aibon oleh Anak Jalanan di Kota Makassar dalam Perspektif Hukum Islam. Universitas Islam Negeri Alauddin Makassar.

Sulistyawati, I. P., Wijanarko, N., \& Fadhilah, S. (2014). Hubungan Tingkat Pengetahuan Siswa-siswi Kelas XI Tentang HIV dan AIDS dengan Sikap Terhadap HIV dan AIDS di SMA N 1 Temanggung Tahun 2012. Jurnal Kesehatan Gubayo, 1(1), 23-30.

Thulasirajah, S., Michaud, J., Doja, A., \& McMillan, H. J. (2020). Inhaled Solvent Abuse 
Mimicking Chronic Inflammatory Demyelinating Polyradiculoneuropathy. Child Neurology Open, 7, $2329048 X 20934914$.

Utomo, L. P. (2017). Penyalahgunaan NAPZA di Indonesia. Komunitas, 9(2), 96-120.

Van Ryzin, M. J., Roseth, C. J., Fosco, G. M., Lee, Y., \& Chen, I.-C. (2016). A componentcentered meta-analysis of family-based prevention programs for adolescent substance use. Clinical Psychology Review, 45, 72-80.

Vázquez, J. J., Berríos, A. E., Bonilla, E., \& Suarez, A. C. (2019). Homeless people in León (Nicaragua): Conceptualizing and measuring homelessness in a developing country. American Journal of Orthopsychiatry, 89(2), 296.

von Stumm, S. (2017). Socioeconomic status amplifies the achievement gap throughout compulsory education independent of intelligence. Intelligence, 60, 57-62.

Yurtseven, A., Türksoylu, M., Karapınar, B., \& Saz, E. U. (2018). A" glue sniffer" teenager with anuric renal failure and hepatitis. The Turkish Journal of Pediatrics, 60(2), 206209. 
